\title{
Factor Affecting Capital Adequacy: Major Factor for Bank to Develop Business Growth in Indonesia in 2013-2017
}

\author{
Novia Rachmawati \\ Department of Magister Management, STIE Perbanas Surabaya, Su \\ e-mail:noviarachmaaa@gmail.com
}

\begin{abstract}
Capital adequacy is a major factor for a bank to be able to develop its business growth. The level of capital adequacy of banks in Indonesia is far above from average CAR of banks in the ASEAN region and peer groups. The high level of capital adequacy in Indonesia is a cautious response from banks in lending amidst from the weak growth of Risk Weighted Assets (RWA). This study aims to determine the effect of non-performing loans (NPLs), Working Capital to Total Assets Ratio (WCTA), Operational Costs / Operating Income (BOPO), Good Corporate Governance (GCG) and Return on Assets (ROA) on the Bank's capital adequacy National Private Public in Indonesia. In this study, the population was used as the object of research was the National Private Commercial Bank listed on the Indonesia Stock Exchange. The sample in this study was taken by pooling data, which is a combination of time series and crosssection during the period of 2013 to 2017. Data were analyzed using Multiple Regression analysis accompanied by a classic assumption test. The results show that there are Non Performing Loan (NPL) and Good Corporate Governance variables did not significantly influence the Capital Adequacy Ratio (CAR) of national private banking companies. And Test results show that there are Working Capital to Total Assets Ratio (WCTA), Operating Costs / Operating Income (BOPO) and Return On Assets (ROA) have a significant positive effect on Capital Adequacy Ratio (CAR) in national private banking companies. This finding is expected to improve the performance of capital adequacy bank from National Private Public in Indonesia.
\end{abstract}

Keywords-Non Performing Loans, Working Capital to Total Assets Ratio, Operating Costs / Operating Income, Good Corporate Governance, Return On Assets, Capital Adequacy.

\section{INTRODUCTION}

Cap APITAL adequacy is a major factor for a bank to be able to develop business growth of Banks. Bank's capital resilience was continued to increase to declining credit growth and rising bank's profitability in 2016. In December 2016, the bank's Capital Adequacy Ratio (CAR) reached $22.7 \%$, and it is increase from 2015 which only reached $21.2 \%$ (Figure 1). The value greater of CAR reflects the better ability of banks in dealing the possibility of loss risk. However, this is an indicator of a risk-weighted asset, that is getting bigger, Bank must raise bank's capital and cause higher CAR. CAR's levels of Indonesian banks are far above the average CAR's level of banks in the ASEAN region and peer groups (Figure 2). This shows that CAR in Indonesia is still high in minimum capital to cope with the risks incurred, CAR required by banks tends to be high compared to other countries. The high level of capital adequacy in Indonesia is a cautious response from lending amidst because weak growth of Risk Weighted Assets

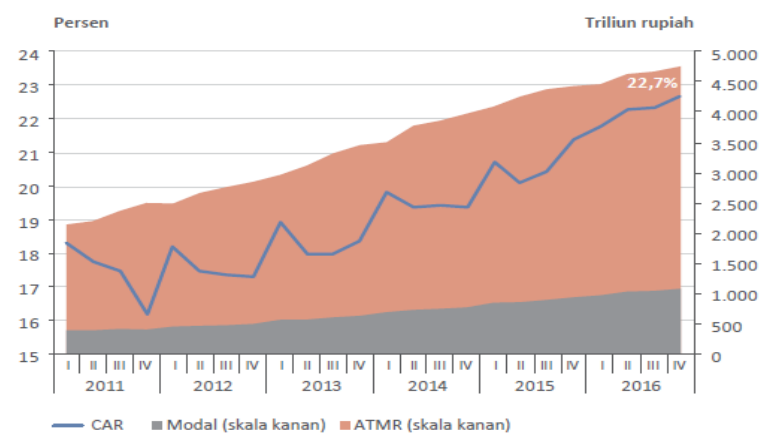

Figure 1. Capital Adequacy of Indonesian Banks.

(RWA).

Based on government regulations regarding the soundness of commercial banks, each bank strives to maintain the value of a company's CAR in order to maintain the soundness of the Bank. The selection of the CAR variable as the dependent variable is because CAR is a very important indicator according to Bank Indonesia in maintaining the soundness of the bank. Where the Capital Adequacy Ratio (CAR) is the ratio of the bank's performance as a measure of the adequacy of capital owned by the bank to support assets that contain or generate risk, for example loans granted. CAR is an indicator of a bank's ability to cover a decline in assets as a result of bank losses caused by risky assets.

Many factors affect the high Capital Adequacy Ratio (CAR) of banks in Indonesia, one of which is credit risk. Banking credit growth slowed from $10.5 \%$ to $7.9 \%$ in 2016 , the lowest growth since 2002. On the demand side, the weakening of bank credit is in line with the condition of corporations that are still consolidating and tends to delay business expansion. While from the supply side, there is a tendency for banks to be more careful in extending credit due to the increase in Non-Performing Loans (NPLs) throughout 2016. In line with this, it has caused banks to be cautious in channeling loans amid weak economic growth so that the growth of assets Risk Weighted (RWA) causes an increase in the capital of Indonesian banks. Liquidity also affects capital adequacy, a high liquidity will cause CAR will also increase, because with an increase in credit provided by the bank will affect credit risk that will occur, so that the required capital adequacy will increase. Looking at the phenomenon of banking in Indonesia which is experiencing illiquid due to insufficient CAR levels, it can be seen that there is a relationship between liquidity ratios 
The $1^{\text {st }}$ International Conference on Business and Engineering Management (IConBEM 2020)

February $1^{\text {st }} 2020$, Institut Teknologi Sepuluh Nopember, Surabaya, Indonesia

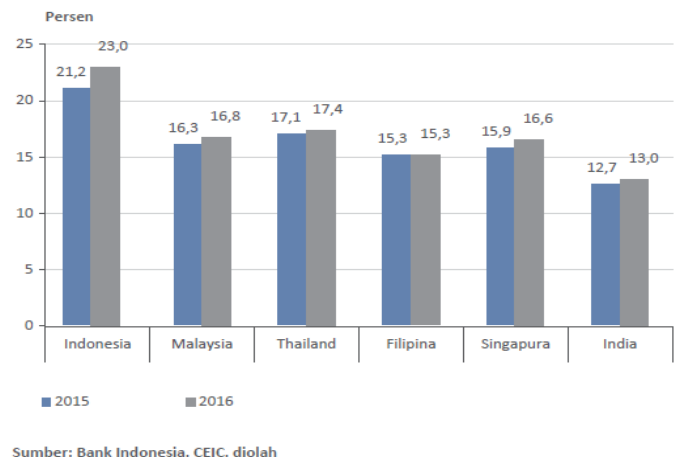

Figure 2. Capital Adequacy of Indonesian Banking and Peer countries.

and CARs. Where liquidity is the ability of banks to meet short-term obligations when billed (Kasmir, 2009). Banking efficiency is also able to influence the high capital adequacy of banks in Indonesia. In 2016, banking efficiency decreased, this is reflected in the ratio of the Operational Cost to Operational Income (BOPO) of the banking industry which slightly increased from $82.2 \%$ in 2015 to $82.8 \%$ in 2016 (Figure 3). In fact, throughout 2016, efficiency has increased because BOPO continues to decline, but experienced a surge at the end of semester IV in 2016.

Another influence is Good Corporate Governance which is able to make it easier to obtain capital, so that it has a positive effect on financial performance which in turn makes capital adequacy effective and reduces losses that are at risk of occurring. Many factors affect the high Capital Adequacy Ratio (CAR) of banks in Indonesia, one of which is credit risk. Profitability is also able to influence the Capital Adequacy Ratio (CAR). However, in Graph 1.3, profitability was maintained stable from 2015 to 2016 because banks made efforts to increase fee-based income as an alternative to income other than interest so that profitability could be maintained to offset an increase in Operating Costs to Operating Income (BOPO).

Based on the background stated, the researcher proposes a study entitled "Effect of Capital Adequacy Factors: the main factor for banks to develop business growth in Indonesia in the period 2013-2017".

\section{RESEARCH QUESTIONS}

Do Non-Performing Loans, Working Capital to Total Assets Ratio, Operational Costs / Operating Income, Good Corporate Governance, Return On Assets affect the Capital Adequacy of National Private Public Banks?

\section{LITERATURE REVIEW}

\section{A. Effects of credit risk on capital adequacy}

Credit risk is the risk due to the failure of the debtor and / or other parties in fulfilling the obligation to pay off credit to the bank (Indonesian Bankers Association, 2015: 67). The financial ratios used for this credit risk are Non-Performing

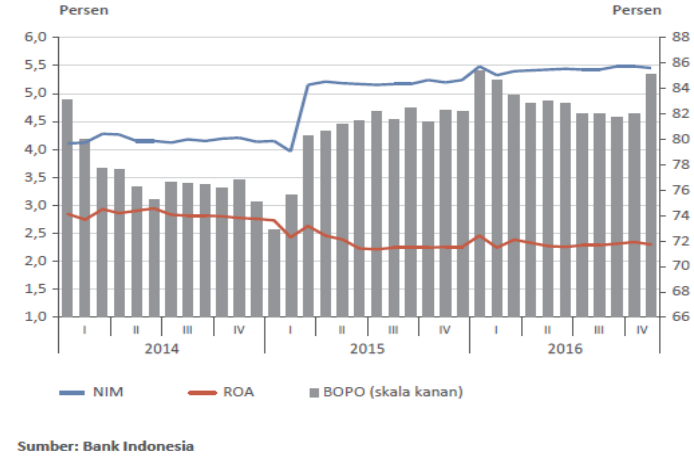

Figure 3. Development of Indonesian Banking Efficiency.

Loans (NPLs). Non-Performing Loans (NPLs) increased due to increased non-performing loans compared to the total loans granted so that bad payments from bank debtors increased causing customer defaults. This causes credit risk to increase, so that the burden of reserves is increased compared to bank revenue due to a significant increase in credit risk to the bank, so the bank may experience impaired ability to pay to the source of funds. Thus causing a decrease in bank profit income in the year, which caused a decline in bank performance. Declining bank performance causes profitability to decline and bank reserves also decline. The bank must also provide a reserve of funds in the bank's minimum capital in accordance with BI regulations. So that increased credit risk can affect the decline in bank capital adequacy. However, Nuviyanti and Achmad Herlanto Anggono's (2014)[20] research results show that NPL has a positive effect on Capital Adequacy Ratio (CAR). This means that an increase in the level of NPL will affect the increase in the level of credit risk, so that credit risk will affect the increase in capital reserves provided. Yet in accordance with the relationship that has been disclosed that credit risk should affect the decline in profits which ultimately causes a decrease in capital adequacy.

The results of research from Osama A. El-Ansary and Hassan M. Hafez (2015)[22] get credit risk results show that it is significantly negatively correlated with the capital adequacy ratio. The most dominant element in determining the magnitude of risk faced by banks is the bank's credit portfolio, which generally covers a portion of $60 \%$ to $90 \%$ of the total value of the bank's assets (Masyhud Ali, 2004: 281)[18]. This explains that the increased NPLs greatly affect the increase in credit risk so as to be able to influence the decline in profits generated so as to affect the adequacy of capital that must be reserved by banks, so the higher the credit risk, the less capital reserved by banks. Based on the explanation above, the first hypothesis that was built in this study is:

$\mathrm{H}_{1}$ : credit risk has a significant negative effect on capital adequacy.

\section{B. Effect of liquidity on capital adequacy}


The $1^{\text {st }}$ International Conference on Business and Engineering Management (IConBEM 2020)

February $1^{\text {st }} 2020$, Institut Teknologi Sepuluh Nopember, Surabaya, Indonesia

Table 1.

Summary of Research

\begin{tabular}{|c|c|c|}
\hline No & Variables & Operationalization \\
\hline 1 & CAR (Capital Adequacy Ratio) & $\begin{array}{l}\text { Capital divided by risk-weighted assets capital consist of core capital }+ \text { supplementary } \\
\text { capital + additional supplementary capital }\end{array}$ \\
\hline 2 & NPL (Non-Performing Loan) & Non-performing loans divided by total loans \\
\hline 3 & WCTA (Working Capital to Total Assets Ratio) & Working capital divided total assets \\
\hline 4 & Operational efficiency & Operating expenses divided by operating income \\
\hline 5 & GCG (Good Corporate Governance) & $\begin{array}{l}\text { Composite ranking of the results of self-assessment of the implementation of Good } \\
\text { Corporate Governance of the Bank. }\end{array}$ \\
\hline 6 & ROA (Return On Assets) & Net income before taxes divided by total assets \\
\hline
\end{tabular}

Table 2.

Descriptive Analysis of Dependent and Independent Variable

\begin{tabular}{|c|c|c|c|c|c|}
\hline \multirow{2}{*}{ Variable } & \multicolumn{5}{|c|}{ Tahun } \\
\hline & 2013 & 2014 & 2015 & 2016 & 2017 \\
\hline CAR (Capital Adequacy Ratio) & $15.70 \%$ & $15.48 \%$ & $17.18 \%$ & $16.76 \%$ & $17.45 \%$ \\
\hline NPL (Non-Performing Loan) & $9.04 \%$ & $2.56 \%$ & $5.96 \%$ & $3.74 \%$ & $4.14 \%$ \\
\hline WCTA (Working Capital to Total Assets Ratio) & $19.00 \%$ & $19.30 \%$ & $22.58 \%$ & $22.11 \%$ & $19.61 \%$ \\
\hline Operational efficiency & $84.97 \%$ & $89.91 \%$ & $95.31 \%$ & $103.06 \%$ & $92.54 \%$ \\
\hline GCG (Good Corporate Governance) & 0.592 & 0.558 & 0.532 & 0.527 & 0.558 \\
\hline ROA (Return On Assets) & $1.37 \%$ & $1.09 \%$ & $0.96 \%$ & $0.54 \%$ & $1.30 \%$ \\
\hline
\end{tabular}

Source : Data Processed

Liquidity is the company's ability to meet its short-term obligations. Liquidity risk management is carried out to determine the pattern of cash flow (cash flow) in various conditions. One that can be used is Working Capital to Total Assets Ratio. Working Capital to Total Assets Ratio is used to measure liquidity of total assets and net working capital positions. The results of the study of Parvesh Kumar Aspal, and Afroze Nazneen (2014)[23] found that liquidity (Liquid Asset to Total Asset Ratio) had a significant positive effect on capital adequacy which showed that increased bank liquidity reflected the ability of banks to meet their credit demand and cash flow needs. So that it will increase the capital adequacy ratio that will be used. This is consistent with the results of research by Mohammed T. Abusharba, Iwan Triyuwono, Munawar Ismail and Aulia F. Rahman (2013)[19] who obtained liquidity results had a significant positive effect on capital adequacy which showed that banks with good liquidity performance tended to improve bank capital. Increased liquidity due to current assets increases compared to current liabilities to be paid and total assets. Increased current assets cause an increase in income compared to the burden of reserves that must be done by banks. Thus causing an increase in the profit and performance of the bank. Improved bank performance led to an increase in bank capital adequacy in that year. Based on the explanation above, the second hypothesis developed in this study is:

$\mathrm{H}_{2}$ : Liquidity has a significant positive effect on capital adequacy.

\section{Effect of liquidity on capital adequacy}

Liquidity is the company's ability to meet its short-term obligations. Liquidity risk management is carried out to determine the pattern of cash flow in various conditions. One that can be used is Working Capital to Total Assets Ratio. Working Capital to Total Assets Ratio is used to measure liquidity of total assets and net working capital positions. The results of the study of Parvesh Kumar Asphalt, and Afroze Nazneen (2014)[23] found that liquidity (Liquid Asset to Total Asset Ratio) had a significant positive effect on capital adequacy which showed that increased bank liquidity reflected the ability of banks to meet their credit demand and cash flow needs. So that it will increase the capital adequacy ratio that will be used. This is consistent with the results of research by Mohammed T. Abusharba, Iwan Triyuwono, Munawar Ismail and Aulia F. Rahman (2013) who obtained liquidity results had a significant positive effect on capital adequacy which showed that banks with good liquidity performance tended to improve capital bank. Increased liquidity due to current assets increases compared to current liabilities to be paid and total assets. Increased current assets cause an increase in income compared to the burden of reserves that must be done by banks. Thus causing an increase in the profit and performance of the bank. Improved bank performance led to an increase in bank capital adequacy in that year. Based on the explanation above, the second hypothesis developed in this study is:

$\mathrm{H}_{3}$ : Liquidity has a significant positive effect on capital adequacy.

\section{Effect of efficiency on capital adequacy}

Efficiency is a measure of comparing input use plans with actual usage or other actual use. The ratio used is the ratio of operating costs / operating income, which is the ratio used to measure the level of efficiency and the ability of banks to carry out their operations. Nuviyanti and Achmad Herlanto Anggono's (2014)[20] and Obiakor Rowland Tochukwu's (2016)[21] research results show that Operating Expenses on Operating Income have a significant negative effect on the Capital Adequacy Ratio (CAR) which shows that an increase in bank operating costs / operating income reflects an increase in operational costs will affect the capital needed by a bank. So that it will increase the capital adequacy ratio that will be used. This is due to an increase in operating costs / operating income which is also influenced by an increase in bad debts, so the operational burden for settlement is increasing. Which causes a decrease in profits due to an increase in the burden of reserves compared to the income generated by banks. Thus reducing bank capital 
The $1^{\text {st }}$ International Conference on Business and Engineering Management (IConBEM 2020)

February $1^{\text {st }} 2020$, Institut Teknologi Sepuluh Nopember, Surabaya, Indonesia

adequacy. Based on the explanation above, the third hypothesis developed in this study is:

$\mathrm{H}_{3}$ : efficiency has a significant negative effect on capital adequacy.

\section{E.Effect of Good Corporate Governance on capital adequacy ratio}

Good Corporate Governance has a role to "ensure" or "guarantee" that management is carried out "properly". Good management will develop the organization (Djokosantoso Moeljono, 2005: 9)[5]. Prasojo's research results in 2015 found that Good Corporate Governance had a significant positive effect on capital adequacy[24]. The smaller the rating value of Good Corporate Governance, the better the bank will be in implementing Good Corporate Governance in accordance with the provisions. With good implementation of Good Corporate Governance, it will affect the performance of the stakeholders, which will affect the performance of the bank. The higher the bank's performance, it will cause an increase in profits generated due to increased revenue thereby increasing the bank's capital adequacy. Based on the explanation above, the fourth hypothesis developed in this study is:

$\mathrm{H}_{4}$ : Good Corporate Governance has a significant positive effect on capital adequacy ratio.

\section{F. Effect of profitability on capital adequacy}

Profitability ratios are ratios that assess a company's ability to find profits. This is indicated by the profits generated from sales and investment income (Kasmir, 2011: 196)[13]. Nuviyanti and Achmad Herlanto Anggono's (2014)[20] research results show that return on assets has a positive effect on capital adequacy ratio (CAR). Other research results from Osama A. El-Ansary and Hassan M. Hafez (2015)[22] get results for the period before 2008 ROA has a positive and significant effect on CAR. This shows that the higher the capital adequacy will increase the minimum capital of the bank. This is because along with increasing profits, banks have higher incentives to protect their owners' capital. The results of research from Keynes Irawan, and Achmad Herlanto Anggono (2015)[15], Gilang Ramadha, Marlina Widiyanti, and Taufik (2016)[17], Leila Bateni, Hamidreza Vakilifard and Farshid Asghari (2014)[16] found that ROA had a positive effect on the capital adequacy ratio. This is also supported by research results from Mohammed T. Abusharba, Iwan Triyuwono, Munawar Ismail and Aulia F. Rahman (2013)[19] showing that profitability is positively related to CAR. Based on the explanation above, the fifth hypothesis built in this study is:

$\mathrm{H}_{5}$ : profitability has a significant positive effect on capital adequacy.

\section{RESEARCH METHODOLOGY}

The population of this study is private public banks that went in $2013-2017$. The sampling technique is purposive sampling, based on criteria set by the researchers. The criteria are follows: 1) National private banking companies that publish financial statements for 5 consecutive years from 2013 to 2017 that are reported to the Financial Services Authority as holders of monetary authority, 2) National private commercial banks with core capital of at least Rp.5,000. 000,000,000.00 (five trillion rupiahs) up to less than $30,000,000,000,000.00$ (thirty trillion rupiahs) (book banks 2 and 3). In this test the dependent variable is CAR which is the variable whose existence is influenced by the independent variable.

The empirical model is develop as follows:

$C A R=\alpha+\beta_{1} N P L+\beta_{2} W C T A+\beta_{3} O E+\beta_{4} G C G+$ $\beta_{5} R O A+e$

Variabel is used in the empirical model is summarized in Table 1. Further details of CAR, in line with the standards set by the Bank of International Settlements (BIS), all banks in Indonesia are required to provide a minimum capital of $8 \%$ of risk weighted assets. While operational efficiency ratio has a best figure if it is below $90 \%$. If ratio exceeds $90 \%$, that is close to $100 \%$, then the bank can be categorized as inefficient in running its operations. A healthy bank also has net NPL ratio below 5\%, composit ranking GCG below 3,5 and liquidity magnitude between $78 \%$ to $92 \%$.

\section{FINDINGS}

\section{A. Descriptive Statistics}

Based on the criteria, the sample in this study is 7 national private banks listed on the IDX, namely (7 companies X 5 years $=35$ national private banking financial statements). Table 2 is the descriptive data for categories banks.

All indicator proved National Private Public Bank in Indonesia have good performance because all indicators met the standards set by Bank Indonesia.

\section{B. Regression Analysis}

Testing hypotheses by using regression tests have passed the test of normality, multicolearity, autocorrelation and heteroskedasticity. While the results of the regression tests can be seen in Table 3 .

Based on Table 3, the regression equation model is obtained as follows:

$\mathrm{CAR}=-0,099+0,007 \mathrm{NPL}+0,143 \mathrm{WCTA}+0,193 \mathrm{OE}+$ $0,026 \mathrm{GCG}+0,051 \mathrm{ROA}+\mathrm{e}$

1) Effect of Non-Performing Loans (NPL) on Capital Adequacy Ratio (CAR)

Table 5.2, shows that the value of the Non Performing Loan (NPL) variable (X1) at the significance level of 0.946> $5 \%$. So partially the Non Performing Loan (NPL) (X1) variable does not significantly influence the Capital Adequacy Ratio (CAR) (Y) in the national private banking companies that went public in the 2013-2017 period. 
The $1^{\text {st }}$ International Conference on Business and Engineering Management (IConBEM 2020)

February $1^{\text {st }} 2020$, Institut Teknologi Sepuluh Nopember, Surabaya, Indonesia

This result does not support the proposed hypothesis. This means that the increasing Non Performing Loans (NPLs) means the bank has a loss, this is due to the increase in nonperforming loans owned by banks, so that it can have a negative impact on banks and capital and Capital Adequacy Ratio (CAR) decreases due to owned capital companies are used to cover the problem loans faced by banks.

Non Performing Loan (NPL) credit risk does not affect the core capital adequacy ratio of national private banking companies, because if credit risk increases marked by an increase in non-performing loans (NPL), the number of nonperforming loans will increase and banks must increase their fund reserves, thereby reducing profit obtained and capital will be reduced, causing the core capital adequacy ratio to decrease so that the Non performing loan (NPL) has no effect on the capital adequacy ratio (CAR). The increase in non-performing loans (NPLs) is caused by an increase in the percentage of total non-performing loans greater than the percentage increase in total loans channeled as a result of the provision of costs will be greater than the interest income. The results of previous studies that also support the effect of NPLs on the capital adequacy ratio measured by CAR were carried out by Anjani and Purnawati (2014) who found that there was no significant effect between NPLs on CAR.

\section{2) Influence between variable Operating Costs / Operating Income (OE) on Capital Adequacy Ratio (CAR).}

Based on table 5.2, the t test above can be seen that the value of the variable operational costs / operating income (BOPO), at a significance level of $0,000<5 \%$. So partially the operational cost / operating income (BOPO) variable, has a significant effect on the Capital Adequacy Ratio (CAR) of national private banking companies that went public in 2013-2017.

The test results show that, there is an influence between the ratio of $\mathrm{BOPO}$ to capital adequacy ratio (CAR), considering that $\mathrm{BOPO}$ is a ratio used to measure operational risk. If the national private banking company is less efficient in controlling operational costs when compared with the acquisition of operating income. Then this condition will cause the bank's operating profit to be low and certainly one aspect that can increase the value of the capital adequacy ratio (CAR) will be low. With the low operating profit, the capital adequacy ratio (CAR) value of national private banking companies will also be low. The results of this study are in line with the results of research Cahyono and Anggraeni (2015).

\section{3) Effect of Good Corporate Governance variables on Capital Adequacy Ratio (CAR).}

Based on table 5.2, the t test above can be seen that the value of the variable Good Corporate Governance at a significance level of $0.803>5 \%$. So partially the Good Corporate Governance variable does not significantly influence the Capital Adequacy Ratio (CAR) of national private banking companies that went public in 2013-2017. The results of research that are insignificant and not in accordance with the direction of the hypothesis relationship can be explained that if the composite value of good corporate governance is high then the bank has a high capital adequacy ratio (CAR), conversely if the composite value of good corporate governance is low then the bank has a value of the capital adequacy ratio (CAR ) The low one. The capital adequacy ratio (CAR) variable is a variable that has two meanings. A capital adequacy ratio (CAR) that is too low can threaten bank capital because banks can be disrupted if the bank is exposed to risk. Meanwhile, when the capital adequacy ratio (CAR) is very high too, this is also not good for banks because banks are unable to carry out their functions for lending. The size of the capital adequacy ratio (CAR) in this study cannot be influenced by good corporate governance in national private banking companies.

The results of this study are in line with research conducted by Ratnasari, Putri, (2016) stating that the variable PDN, BOPO, FBIR, good corporate governance partially has an insignificant negative effect on CAR at the National Private Foreign Exchange Bank for the period 2010 to 2014 .

\section{4) Effect between the variable Return on Assets (ROA) and the Capital Adequacy Ratio (CAR).}

Based on table 5.2, the $t$ test above can be seen that the value of the variable Return On Assets (ROA), at a significance level of $0.005<5 \%$. So partially the Return on Assets (ROA) variable has a significant effect on the Capital Adequacy Ratio (CAR) of national private banking companies that went public in 2013-2017.

The positive relationship obtained in this study means that Return On Assets (ROA) is inversely proportional to CAR. If the Return On Assets (ROA) increase, the Capital Adequacy Ratio (CAR) will increase and vice versa if the Return On Asset (ROA) decreases, the Capital Adequacy Ratio (CAR) will decrease. Bank profits will be prioritized to increase bank capital, therefore the higher the value of Return On Assets (ROA) the higher the Capital Adequacy Ratio (CAR) of national private banking companies. Increased profitability indicates that the profit generated is quite high due to the use or management of assets by the national private banks effectively.

\section{CONCLUSIONS AND RECOMMENDATIONS}

From the results, the factors affecting Capital adequacy national private public banks in Indonesia are Working Capital to Total Assets Ratio, Operating Costs/Operating Income, Return On Assets. The results showed that national private public banks in Indonesia can conduct capital adequacy so well that assets can be improved. This needs to be maintained and continually improved. Non Performing Loans (NPLs) do not significantly to influence the Capital Adequacy Ratio (CAR) because if credit risk increases marked by an increase in non-performing loans (NPLs) it will result in the increasing number of non-performing loans and banks must increase their fund reserves so as to reduce the profits obtained and capital will decrease, causing the core capital adequacy ratio to decrease so that the Non performing loan (NPL) has no effect on the capital adequacy ratio (CAR). Good Corporate Governance does not significantly influence the Capital Adequacy Ratio (CAR) of national private banking companies, because the application of management and governance does not directly affect the capital adequacy in terms of covering losses incurred due to the business activities of Private Commercial Banks National. The limitation of this study is that it only explored 
The $1^{\text {st }}$ International Conference on Business and Engineering Management (IConBEM 2020)

February $1^{\text {st }} 2020$, Institut Teknologi Sepuluh Nopember, Surabaya, Indonesia

internal factors that effected the performance of the banks, for further researches they should add external as well such as inflation, market concentration, gross domestic product and exchange rate. Need to consider the different models that will be used in determining the Capital Adequacy Ratio (CAR) of national private banking companies so that they can see the soundness of banks from different sides. For further researchers, it can add a longer period of time so that research results are more accurate and can describe the overall situation of national private banking companies that go public on the Indonesia Stock Exchange.

\section{REFERENCES}

[1] Djokosantoso Moeljono. 2005. Good Corporate Culture Sebagai Inti Dari Good Corporate Governance. Jakarta : PT Elex Media Komputindo.

[2] Kasmir. 2011. Analisis Laporan Keuangan. Jakarta : Rajawali Pers.

[3] Keynes Irawan dan Achmad Herlanto Anggono. (2015). A Study Of Capital Adequacy Ratio And Its Determinants In Indonesian Banks: A Panel Data Analysis, International Journal of Management and Applied Science. Vol 1, No 9, Pp 98-101. ISSN:2394-7926.

[4] Leila Bateni, Harmidreza Vakilifard, dan Farshid Asghari. (2014). The Influential Factors on Capital Adequacy Ratio in Iranian Banks, International Journal of Economics and Finance. Vol 6 , No 11, Pp 108-116.ISSN 1916-971X, E-ISSN 1916-9728.

[5] M. Gilang Ramadhan, Marlina Widiyanti, dan Taufik. (2016). Pengaruh Current Ratio, Debt To Equity Ratio, Dan Bopo
Terhadap Capital Adequacy Ratio Dengan Return On Assets Sebagai Variabel Intervening Pada Perusahaan Perbanka Syariah di Indonesia, Jurnal Ilmiah Manajemen Bisnis dan Terapan. Vol XIII, No 1, Pp 15-26.

[6] Masyhud Ali. 2004. Asset Liability Management : Menyiasati Risiko Pasar dan Risiko Operasional dalam Perbankan. Jakarta : PT Alex Media Komputindo.

[7] Mohammed T. Abusharba, Iwan Triyuwono, Munawar Ismail, dan Aulia F Rahman, Global Review of Accounting and Finance. Vol 4, No 1, Pp 159-170.

[8] Nuviyanti dan Achmad Herlanto Anggono. (2014). Determinants of Capital Adequacy Ratio (CAR) in 19 Commercial Banks (Case Study : Period 2008 - 2009, Journal of Business and Management. Vol.3, No.7, Pp 752-764.

[9] Obiakor Rowland Tochukwu. 2016. Capital Adequacy and Risk Management: A Study of the Nigerian Banking Sector, International Journal of Innovative Science, Engineering and $\begin{array}{lllll}\text { Technology. (online). } \mathrm{Vol} \quad 3, & \text { No 7, } & \mathrm{Pp} & 342-354 .\end{array}$ (http://www.ijiset.com diakses pada tanggal 8 Agustus 2017). ISSN 2348-7968.

[10] Osama A. El-Ansary, dan Hassan M Hafez. 2015. Determinants of Capital Adequacy Ratio : An Empirical Study On Egyptian Banks, Journal Corporate Ownership and Control. Vol 13, No 1, Pp 806816.

[11] Parvesh Kumar Aspal dan Afroze Nazneen. 2014. An Empirical Analysis of Capital Adequacy in the Indian Private Sector Banks, American Journal of Research Communication. (online). Vol 2, No 11, Pp 28-42. (http://www.usa-journals.com diakses tanggal 8 Agustus 2017) ISSN : 2325-4076.

[12] Prasojo. (2015). Pengaruh Penerapan Good Corporate Governance terhadap Kinerja Keuangan Bank Syariah, Jurnal Dinamika Akutansi dan Bisnis. Vol 2, No 1, Pp 59-69. 